\title{
MODELLING FOR EVALUATIONS OF CALL CENTER FOR PUBLIC TRAFFIC AND TRANSPORT SYSTEMS
}

\author{
Slaven Tica ${ }^{1}$, Valentina Radojičić ${ }^{2}$, Goran Marković ${ }^{3}$, Dejan Marković ${ }^{4}$
}

\author{
University of Belgrade, Faculty of Traffic and Transport Engineering, \\ Vojvode Stepe 305, 11000 Belgrade, Serbia \\ E-mails: ${ }^{1}$ tice@eunet.rs (corresponding author); ${ }^{2}$ valentin@sf.bg.ac.rs; \\ ${ }^{3}$ g.markovic@sf.bg.ac.rs; ${ }^{4}$ d.markovic@sf.bg.ac.rs
}

Received 29 September 2009; accepted 6 January 2011

\begin{abstract}
This paper is dealing with functional organization of a call center based on human operator work. Due to significant fluctuations of user demands during the day and from day to day, the determination of required number of agents appears as actual giving the opportunities for efficient management. The purpose of this paper is to develop a mathematical model for optimal resource allocation in a call center in order to provide a satisfactory quality of service at all times, without having more agents than necessary. The objective is to find the best staffing levels or schedule that minimizes the daily costs while satisfying all constraints. To solve this problem, we propose here a two-level dynamic programming (DP) algorithm that determines the required staffing levels by shifts. The algorithm enables optimal allocation of available human resources such that the operation costs are reduced as much as possible. The practical sample is demonstrated in a case of a call center for public traffic and transport systems in metropolitan. The results comparison for different shifts duration is performed.
\end{abstract}

Keywords: agent, call center, dynamic programming, management, operation, service, shift.

Reference to this paper should be made as follows: Tica, S.; Radojičić, V.; Marković, G.; Marković, D. 2011. Modelling for evaluations of call center for public traffic and transport systems, Technological and Economic Development of Economy 17(1): 116-132.

JEL Classification: C02, C61, M54, R48.

\section{Introduction}

Call centers or their contemporary successors contact centers, are the preferred and prevalent way for many companies to communicate with their customers. In the last decade, there has been spectacular growth in retail business conducted by telephone. It has been recognized that a critical factor in a business success in this environment is being able to respond rapidly to customer requests. At the same time, the costs of staffing telephone call centers have become 
a substantial part of business expense. Agent scheduling, or staffing, deals with matching the offered call volume with agents. Thus, it is essential to manage efficiently telephone call centers, so that customer requests are met without excess staffing (Whitt 1999). The objective of a call center is usually to obtain at least a certain minimal service level (SL) for minimal costs (Koole 2004). Mathematics can play an important role in getting the best out of the service level/cost trade-off of call centers (Koole 2007).

As indicated, the call center industry itself is vast and rapidly expanding. It is estimated that about four million people in the United States (3\% of the workforce) work in contact centers, with the number growing by about $20 \%$ per year (U.S. Bureau of Labor Statistics). Many statistics have been collected demonstrating the economic importance of contact centers. In this paper, we aim to contribute to the better design and management of telephone call centers and their organizations. The research effort is important because call centers comprise a large, growing part of the economy and because they are quite complicated (Whitt 2002). Classic call centers are complicated because there are often many types of calls, requiring different service skills, serving multiple classes of customers with different needs. Another reason call centers are complicated is that waiting customers may abandon (Whitt 2005).

Choosing the best plan, finding the best conditions of system functioning or choosing the best management are very difficult tasks. In addition, because of a great variety of problems, complexity of optimization becomes huge. The aim of optimal system management is to find the best variable values in order to minimize or maximize the chosen criteria function. Many decision-making problems may be formulated as global optimization problems (Sakalauskas, Zavadskas 2009). Dynamic programming is a method of solving multi-stage problems in which decisions at one stage become the conditions governing the succeeding stages (Robinett et al. 2005; Bellman 2003). Dynamic programming efficiently solves a broad range of search and optimization problems that exhibit the characteristics of overlapping sub problems and optimal substructure. A problem is said to have optimal substructure if the globally optimal solution can be constructed from locally optimal solutions to sub problems.

In this paper, dynamic programming (DP) method is suggested for determination the optimal number of agents by shift. Seven days period was considered making distinction between workdays, Saturday and Sunday as periods of different demand intensity and time distribution. Multi-dimensionality and large extent of the problem were the reason for leaving the typical approach of DP and applying two-level concept. Such approach has shown a number of advantages. The problem may be solved on the systematic basis, by finding of the local optimums. Simple and easy input data changing for only one or two subsystems is provided offering high convenience of model use in practice.

This paper proposes a staffing algorithm to determine the required number of agents by shifts, which is based on two-level dynamic programming approach. The main goal is to reduce the operational costs of a call center and the number of unsuccessful calls, without having more agents than necessary i.e. the minimum number of agents needed to guarantee the appropriate quality of service at minimum cost (actually revenue minus cost). Significant steps in that direction were made by Borst and Ganet (Borst et al. 2004; Garnett et al. 2000); they included costs in many servers asymptotic. For an overview of contact centers and various mathematical models that have been applied to them, see (Gans et al. 2003). 
The proposed algorithm tries to determine not only the optimal number of agents during the time of the day and the day of the week, but also to provide that all agents be uniformly engaged for full working time. The practical sample was demonstrated in the case of a call center for traffic and transport system in metropolitan. The results comparison was performed for different shifts duration. A software application in Visual BASIC was developed as a simulation tool of corresponding operation of any call center.

The paper is organized in the following way. Section 2 discuses briefly the call center operation. In section 3 we give the problem statement of the optimal allocation of human resources in a call center. Section 4 contains detail description of the proposed two-level DP staffing algorithm. Section 5 is devoted to the description of the obtained optimization results. Finally, the conclusion is given in the Section 6.

\section{Call Centers Background}

A call center is a collection of resources (typically agents and ICT equipment) capable of handling customer contacts by telephone. If the call center handles not only telephone contacts but also contacts by fax, email, and so forth, then it is usually called a customer contact center. A contact center is a collection of resources providing an interface between a service provider and its customers. The classical contact center is a call center, containing a collection of service representatives (agents) who talk to customers over telephone. In a call center, the agents are supported by quite elaborate information and communication technology (ICT) equipment, such as a private branch exchange (PBX), an interactive voce response (IVR) unit, an automatic call distributor (ACD), a personal computer and assorted databases. With a rapid growth of e-commerce, contact between a service provider and its customers is now often called a contact center (Whitt 2002).

Call centers can be categorized along many dimensions. The functions that they provide are highly varied: from customer service, help desk, and emergency response services, to tele-marketing and order taking. They vary greatly in size and geographic dispersion, from small sites with a few agents that take local calls - for example at a medical practice - to large national or international centers in which hundreds or thousands of agents may be on the phone at any time (Gans et al. 2003). Call centers may have only inbounded traffic (customer-generated calls), only outbound traffic (telemarketing) or a combination of these. Inbound call centers are usually supported by interactive voice response (IVR) units, which serve as elaborate answering machines. Outbound call centers may have predictive dialers, which dial before an agent is available, attempting to anticipate when one will be available, thus reducing idle time, but unfortunately leading to some calls without a calling party, thus annoying the called parties (Barber 2002).

The organizational structure of a call center may vary from the very flat - in which essentially all agents are exposed to external calls - to the multi-layered - in which a layer represents a level of expertise - and customers may be transferred through several layers before being served to satisfaction. A central characteristic of a call center is whether it handles inbound or outbound traffic (Gans et al. 2003). Our focus in this article is on inbound call centers and flat organizational structure. 
Call centers usually handle several types of calls, but it is usually not possible or cost effective to have every agent be able to handle every type of call. Thus, the agents tend to have different skills, in different combinations. In such an environment, it is challenging to route calls effectively and determine the staff requirements (Rodney and Whitt 2005).

An important feature of any call center, as well as most other service systems, is that demand for service varies greatly by time of day, as illustrates the Fig. 1. In such circumstances, the main problem is how to set appropriate staffing levels in the face of such time varying demand (Whitt 2007). For a review of staffing methods to cope with time-varying arrivals, see (Green et al. 2001, 2007).

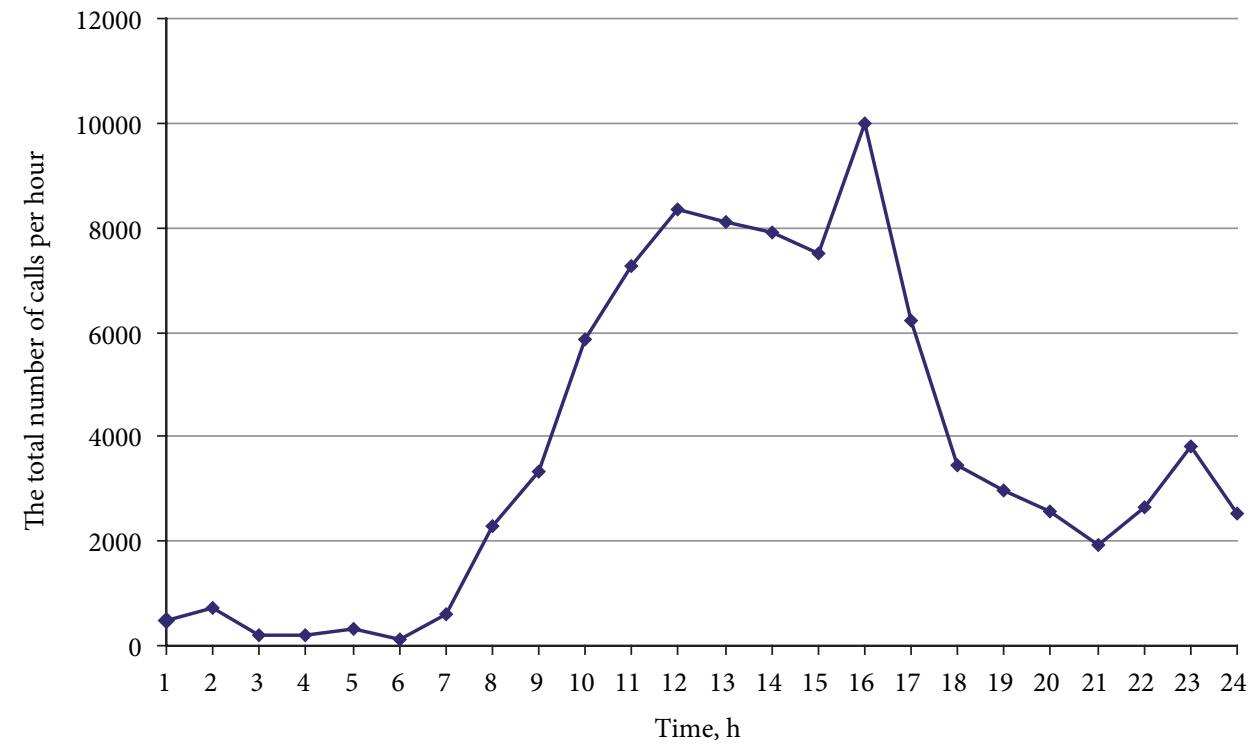

Fig. 1. The total number of calls per hour during the day

The required number of agents is proportional with instantaneous offered load, which is the product of the arrival rate and the average service time (for example: 10.000 calls per hour $\mathrm{x} 0.01 \mathrm{~h}=100$ agents).

\section{Problem Statement}

The optimization problem we discuss here is: how can we set appropriate staffing levels by shifts in the face of time-varying demand? We consider a single call center with a single group of agents, serving a group of callers. In other words, we reflect on standard staffing problem of a single-skill inbound call center. The staffing problem is to determine the required number of agents as a function of time to minimize the operational costs. The goal is to provide a satisfactory quality of service at all times, without having more agents than necessary. Quality of service can be defined as the degree of satisfaction of callers with the 
offered service (Radojicic 2004). This service level consists of many different aspects, related to the quality of the answer, the waiting time of the customer, etc. Here we are concerned with the number of agents required as a function of time, assuming for simplicity that the number can change continuously through time. In pratice, however, staffing changes typically can occur only periodically per shift, so that the staffing level is constant during a shift. The analysis is based on an idealized model of a call center in which the number of employed agents is constant over time, assuming that a new agent is immediately hired to replace each departing agent. It is important to recognize that it may be more effective to provide appropriate flexibility to do real-adjustments than to carefully determine the «best» staffing level in advance (Whitt 2007).

The long-term staffing problem can be expressed as the resource assignment problem: minimize the total agent hours assigned, subject to specified quality of service constraints holding at all times. It is, in fact, the allocation of one resource of volume $S_{1}$ to activities $i=$ $1, \ldots, N$.

Each activity $i$ is assigned a part of resource $x_{i}$ and it is characterized by the efect function $f_{i}, i=1, \ldots, N$. These functions show the efect dependence from volume of resource which is assigned to each activity $i$. The basic assumption is that the efects could be expressed by the same units of measure. Further assumption is additivity, i.e., the total effect of allocation equals to the sum of individual effects. A next one is independence, i.e. resource assignment to some activity has no influence on the effects of other activities. A general optimization task of resource allocation could be defined as follows: to assign resources of quantity $x$ over $N$ activities such that the total effect function is maximized or minimized. In other words, it is neccessery to determine $x_{1}, \ldots, x_{N}$, in order to optimize the criteria function, i.e. the function of total effect $F=\sum_{i=1}^{N} f_{i}\left(x_{i}\right)$, subject to the constraints $\sum_{i=1}^{N} x_{i}=x$ for $x_{i} \geq 0, i=1, \ldots, N$. It is possible to vary the number of activities only at the predefined steps according to the nature of DP procedure.

\section{Two-Level Resource Allocation Algorithm}

Dynamic programming is powerfull tool for solving the assigment problem of one type of resource, nevertheless on the dimension of the number $N$. Since DP procedure is quite computationally intensive, it is the reason why we propose here a two-level DP algorithm for optimal resource allocation, consisting of the coordination level and the subsystem level. The coordination level makes decisions about resources allocation throughout the whole system. The subsystem level makes decisions about resources allocation to the individual subsystems: working day $(w)$, Saturday $(s t)$ and Sunday $(s n)$. Because the individual daily traffic profiles during the working days differ only little in shape and traffic intensity between each other it allows us to form one integral subsystem - working day. The individual daily traffic profiles during the Saturday and Sunday differ in shape and traffic intensity significantly, between each other, so we composed two more subsystems. These individual subsystems allocate the resources to activities. The two-level concept for resource allocation in a call center is illustrated by Fig. 2 . 


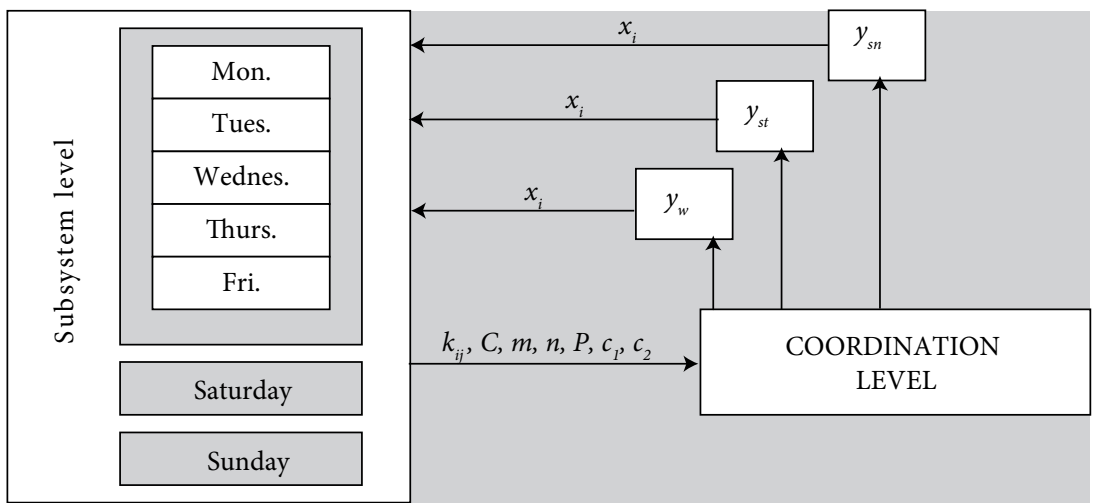

Fig. 2. Two-level resource allocation

Accordingly, the two-level dynamic programming staffing algorithm consists of two-phase optimisation procedure. At the coordination level, the optimal number of agents is assigned to each individual subsystem. At the subsystem level these resources are allocated to activities in order to minimize the cost effect (penalty) function. The penalty function depends on the number of currently engaged agents. The surpluse of agents leads to an additional costs due to agent's inefficient usage - surpluse costs. Otherwise, lacking of agents produce costs due to lost calls - costs due to lost calls. In other words, the average number of one hour arrivals, $k_{i j}$, coresponds to «ideal» number of required agents, $d_{i j}$, without lost calls. The ideal number of agents, $d_{i j}$, is defined by equation (1),

$$
d_{i j}=\frac{k_{i j}}{P},
$$

where are: $i$ - ordinal number of shift, $j$ - ordinal number of one-hour interval during a shift, $k_{i j}$ - the average number of arrivals during one-hour, $P$ - the average number of served calls per agent during one-hour.

We define the penalty function $f_{i}\left(x_{i}\right)$ by following equations:

$$
f_{i}\left(x_{i}\right)=\sum_{j=1}^{m} g\left(d_{i j}\right)=\left\{\begin{array}{l}
c_{1}\left|d_{i j}-x_{i}\right|, \forall d_{i j}<x_{i}, \\
P c_{2}\left|d_{i j}-x_{i}\right|, \forall d_{i j}>x_{i},
\end{array}\right.
$$

where are: $c_{1}$ - agent cost per hour, $c_{2}$ - service price, $P$ - average number of served calls per agent during one-hour, $x_{i}$ - engaged number of agents by shift $i, d_{i j}$ - ideal number of agents, $m$ - shift duration (for example: $4 \mathrm{~h}, 6 \mathrm{~h}$ or $8 \mathrm{~h}$ ).

The more difference between the number of ideal and engaged agents, $d_{i j}-x_{i}$, the penalty function, $f_{i}\left(x_{i}\right)$, increases, as shown by Fig. 3 .

If $d_{i j}<x_{i}$ the penalty function, $f_{i}\left(x_{i}\right)$, increases in proportion with the parameter $c_{1}$, while $d_{i j}>x_{i}$ the penalty function, $f_{i}\left(x_{i}\right)$, increases in proportion with the parameter $c_{2}$.

According that, it is possible to calculate the penalty function values, which is the result of agents surplus or agents lack, during a shift. 


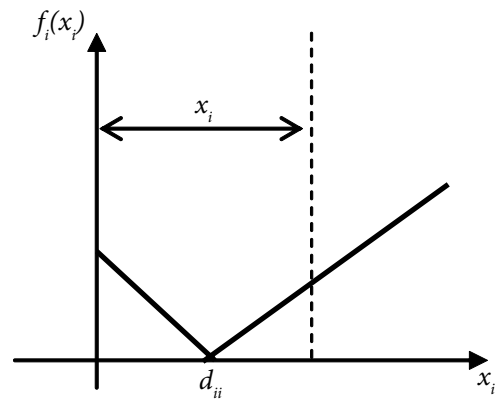

Fig. 3. The penalty function

The penalty function represents the efect function, that has to be minimized. Generally, the efect function could be represented by a piece -wise function with a step $\Delta$, as shown by Fig. 4 . Figure $4 \mathrm{a}$ illustrates the efect function which has a minimal value. It is the area where it is expected to find the optimal resource value. If the minimal value of the efect function could not be found (Figure $4 \mathrm{~b}$ ), then the available resource is not well estimated. In that case the resource, $S$, has to be increased. We assumed the uniform step discretion $\Delta$ of the total resource, $S$. In our case, the resource is the number of agents, therefore it is naturally to assume the unity step of discretion, $\Delta=1$.

The penalty function for the total available resource of agents is given by equation 3 .

$$
F(S)=\min _{\left(y_{w}, y_{s t} y_{s n}\right)}\left[5 F_{w}\left(y_{w}\right)+F_{s t}\left(y_{s t}\right)+F_{s n}\left(y_{s n}\right)\right]
$$

such that the constraint (4) is satisfied:

$$
5 y_{w}+y_{s t}+y_{s n}=S,
$$

where are: $S$ - the total available resource [agent $\mathrm{x}$ shift] $(\mathrm{S}=40 \mathrm{C} / \mathrm{m} ; C$ - the total number of available agents; 40 - normative working time of agent during the week; $m$ - shift duration), $y_{w} y_{s b} y_{s n}-$ the maximal number of agent $\mathrm{x}$ shift for a working day, Saturday and Sunday, respectively.

$F_{w} F_{s t}, F_{s n}$ - the cost functions for a working day, Saturday and Sunday, respectively.

The values of $y_{w} y_{s t}$ and $y_{s n}$ are estimated based on equation (5),

$$
\frac{y_{w}}{K_{w}}=\frac{y_{s t}}{K_{s t}}=\frac{y_{s n}}{K_{s n}}=\frac{S}{5 K_{w}+K_{s t}+K_{s n}},
$$

where are: $K_{r}$ - the average number of calls during a working day, $K_{s}$ - the average number of calls during the Saturday, $K_{n}$ - the average number of calls during the Sunday.

a)

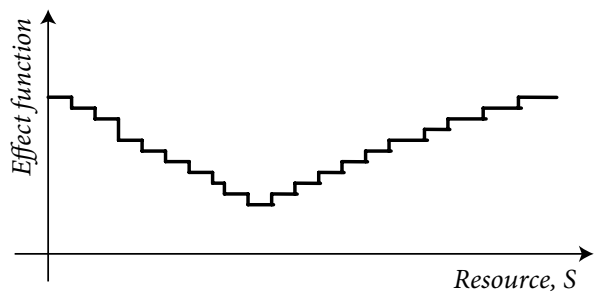

b)

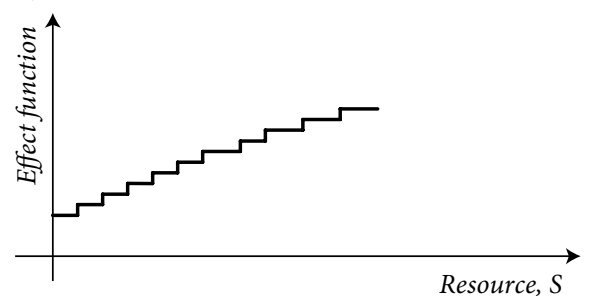

Fig. 4. The Effect function: a) with a minimum value, b) with constant increase 
The optimal numbers of agents, $x_{i}$, by shifts, have to satisfy the condition given by following equation:

$$
5 \sum_{i=1}^{n} x_{i}+\sum_{i=n+1}^{3 n} x_{i}=\frac{40}{m} C,
$$

where are: $n$ - number of shifts during 24 hours, $m$ - shift duration, $C$ - the total number of available agents.

Naturally, since the call center, need to be available permanently during the 24 hours, the number of agent by shift has to satisfy the following constraint:

$$
x_{i} \geq 1 .
$$

The dynamic programming recurrent equations for sub-system level are given by equations (8)-(10):

$$
\begin{gathered}
F_{i}\left(y_{w}\right)=\min _{\mathrm{x}_{\mathrm{i}}}\left[\mathrm{f}_{\mathrm{i}}\left(\mathrm{x}_{\mathrm{i}}\right)+\mathrm{F}_{\mathrm{i}-1}^{*}\left(\mathrm{y}_{\mathrm{w}}-\mathrm{x}_{\mathrm{i}}\right)\right], i=1, \ldots, n, \\
F_{i}\left(y_{s t}\right)=\min _{x_{i}}\left[\mathrm{f}_{\mathrm{i}}\left(\mathrm{x}_{\mathrm{i}}\right)+\mathrm{F}_{\mathrm{i}-1}^{*}\left(\mathrm{y}_{\mathrm{st}}-\mathrm{x}_{\mathrm{i}}\right)\right], i=n+1, . ., 2 n, \\
F_{i}\left(y_{s n}\right)=\min _{x_{i}}\left[\mathrm{f}_{\mathrm{i}}\left(\mathrm{x}_{\mathrm{i}}\right)+\mathrm{F}_{\mathrm{i}-1}^{*}\left(\mathrm{y}_{\mathrm{sn}}-\mathrm{x}_{\mathrm{i}}\right)\right], i=2 n+1, . .3 n .
\end{gathered}
$$

At the coordination level, the total available resource, $S$, is assigned to each sub-system resource: $y_{w}, y_{s t}$ and $y_{s n}$, by applying the following recurrent equations (11)-(13):

$$
\begin{gathered}
F_{w}^{*}(S)=\underset{\mathrm{y}_{\mathrm{w}}}{\min }\left[5 \mathrm{~F}_{\mathrm{w}}\left(\mathrm{y}_{\mathrm{w}}\right)\right], \\
F_{s t}^{*}(S)=\min _{\mathrm{y}_{\mathrm{st}}}\left[\mathrm{F}_{\mathrm{st}}\left(\mathrm{y}_{\mathrm{st}}\right)+\mathrm{F}_{w}^{*}\left(\mathrm{~S}-\mathrm{y}_{\mathrm{st}}\right)\right], \\
F_{s n}^{*}(S)=\min _{\mathrm{y}_{\mathrm{sn}}}\left[\mathrm{F}_{\mathrm{sn}}\left(\mathrm{y}_{\mathrm{sn}}\right)+\mathrm{F}_{\mathrm{st}}^{*}\left(\mathrm{~S}-\mathrm{y}_{\mathrm{sn}}\right)\right] .
\end{gathered}
$$

The optimal solution is obtained by eliminating each resource value, $S$, which does not reduce the effect function.

A software application in Visual basic was developed as the optimization tool for human resource allocation. The graphical user-friendly interface for input data is illustrated by Fig. 5 .

Simple and easy input data changing for only one or two subsystems is provided offering high convenience of model used in practice.

The computational complexity of such approach is improved by reducing the number of calculations and partial results that have to be memorized. Therefore, the CPU times and the required operating memory are reduced.

\section{A Practical Sample}

A practical sample was demonstrated in a case of a Call center for Public Traffic and Transport System in metropolitan, equipped with 68 work stations, each supported with two circuit lines. 


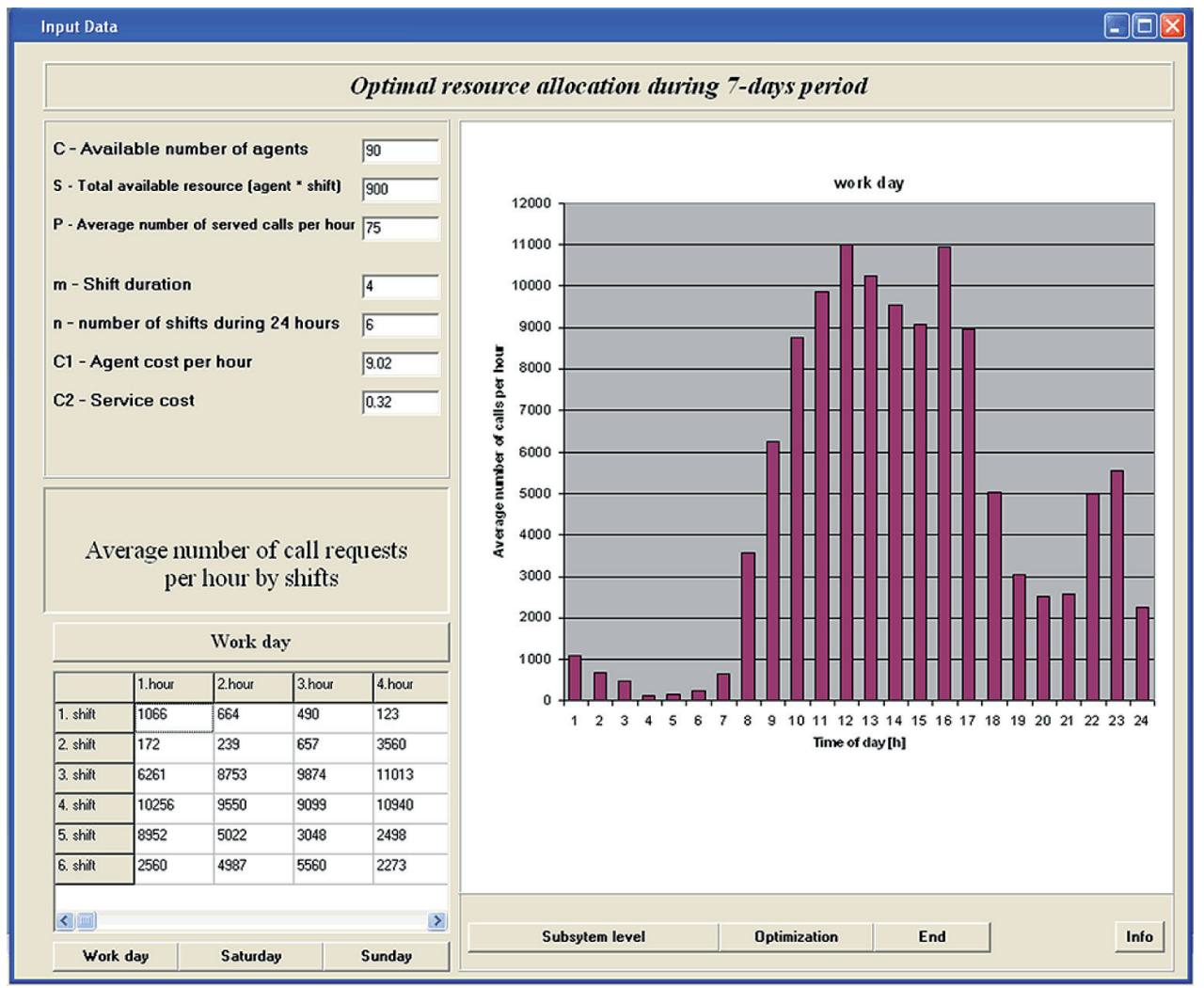

Fig. 5. Graphical interface for input data

The average number of one-hour arrivals, $k_{i j}$, for typical days in a week-Working day, Saturday and Sunday, obtained during the referent measurement period are shown by Fig. 6 .

Given data on the number of calls is used to estimate the hourly agent requirements. The required number of agents is proportional to the instantaneous offered load. Some of the quality of service parameters of the considered call center obtained by measurements are the following: the percentage of successful calls from 10 a.m. to 5 p.m. is $55.9 \%$, the percentage of successful calls from 10 p.m. to 11 p.m. is only $25 \%$, the percentage of unsuccessful calls due to operators occupation from 10 a.m. to 5 p.m. is very large and it goes even up to $40.7 \%$ etc. Because of great number of lost calls, this call center was chosen to demonstrate the method proposed above.

The optimization results could be compared for different shift duration (for example: $\mathrm{m}=4, \mathrm{~m}=6$ or $\mathrm{m}=8$ hours) and traffic input data. For the given total available resource, $S$, DP procedure gives one or more optimums. Moreover, for any resource value less than $S$ and the number of agents by shifts less than $x_{i}$ the optimal solution could be obtained, too.

The software application was tested for different total number of available agents $C=\{100$, $110,120, \ldots\}$. It is assumed that the agent cost per hour and the service price are $c_{1}=9.02(€)$ and $c_{2}=0.32(€)$, respectively. In our practice case, the measurement results show that the 
a)

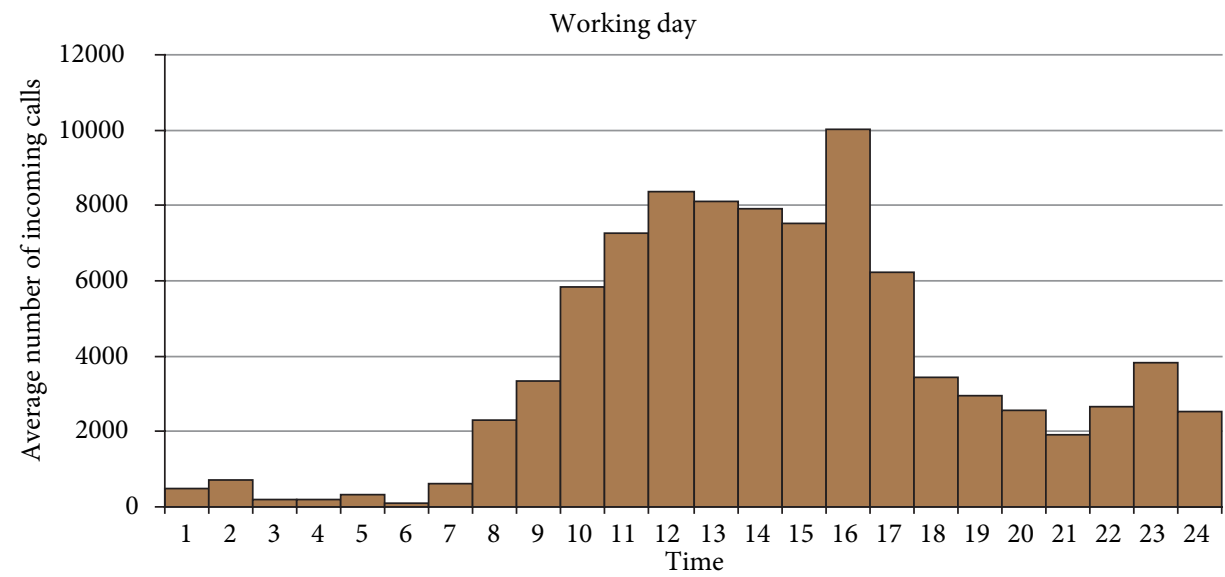

b)

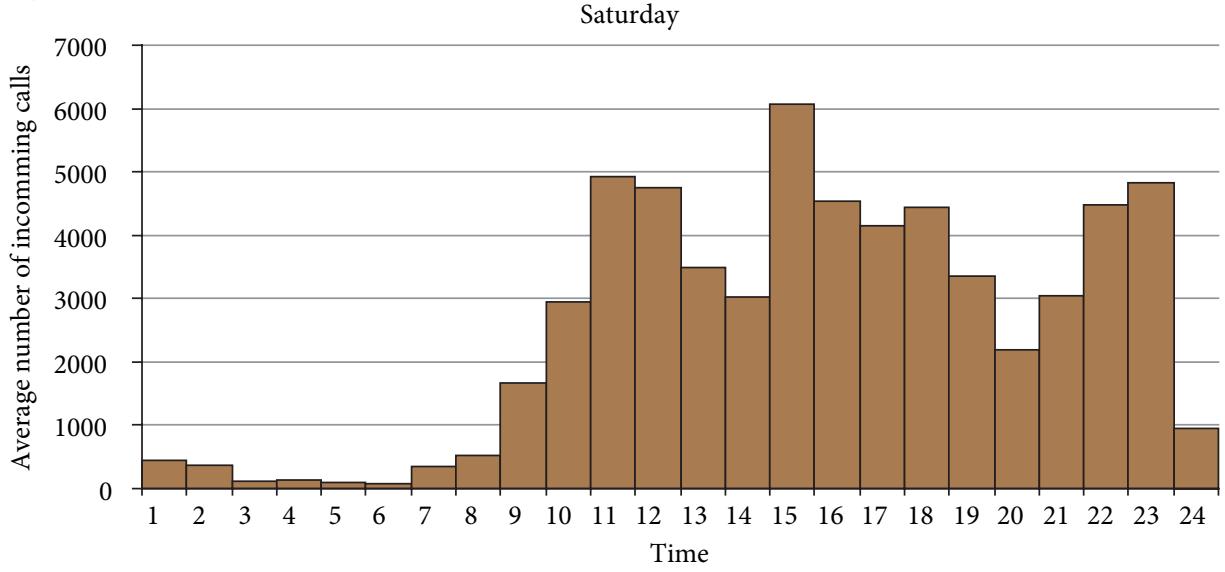

c)

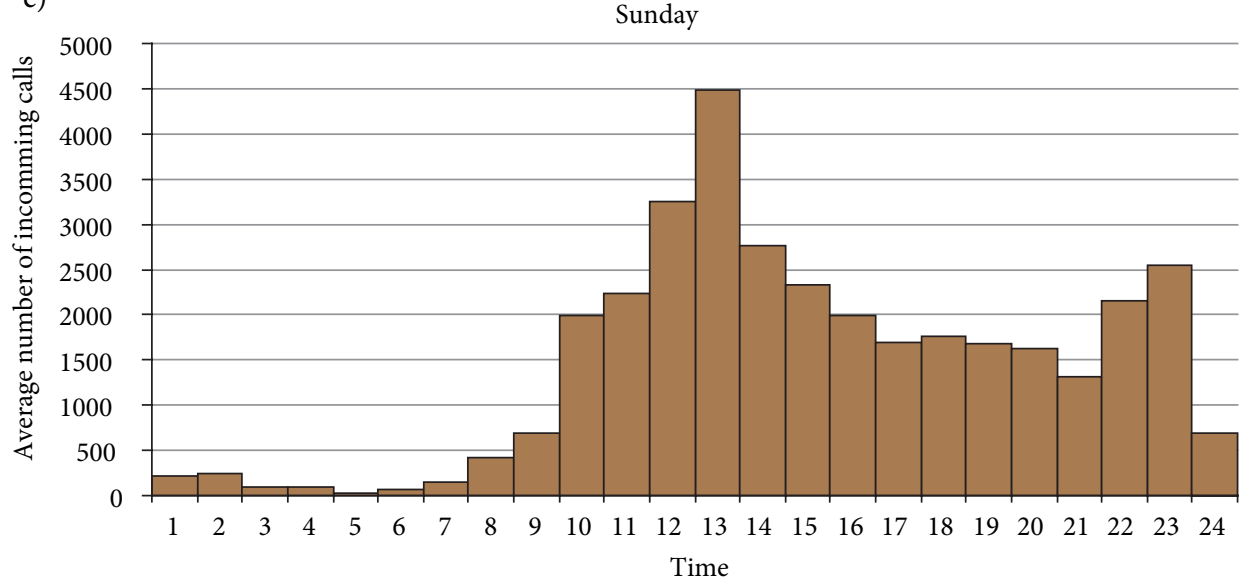

Fig. 6. Traffic profiles during: a) working days, b) Saturday and c) Sunday 
mean holding time does not change significantly during the day due to specific character of this call center service. Namely, the callers always asking the similar requests and agents spent the similar time until answering. Therefore, we assumed the constant mean holding time, $h=40 \mathrm{~s}$, obtained by measurements. Also, taking into account the time breaks of 10 minutes per hour for each agent, the average number of calls that could be served is estimated to $P=75$ calls/hour.

We tested the software application and compare the results for two shifts duration: $m=$ 4 and $m=8$ hours. For given input data, the output results at the subsystem level and the coordination level are shown by Tables $1 \mathrm{a} ; 1 \mathrm{~b} ; 2 \mathrm{a} ; 2 \mathrm{~b} ; 3 \mathrm{a} ; 3 \mathrm{~b} ; 4 \mathrm{a} ; 4 \mathrm{~b} ; 5 \mathrm{a} ; 5 \mathrm{~b} ; 6 \mathrm{a} ; 6 \mathrm{~b}$.

A. Output results for shift duration $m=4$ hours

Table 1a. Optimal resource alocation at subsystem level for $\mathrm{C}=100$ agents

\begin{tabular}{lccc}
\hline The total available resource, $\mathbf{S}$ [agent $\mathbf{x}$ shift] & $\mathbf{y}_{\mathbf{w}}$ & $\mathbf{y}_{\text {st }}$ & $\mathbf{y}_{\text {sn }}$ \\
\hline $\mathrm{S}=1000$ & 176 & 53 & 67 \\
\hline
\end{tabular}

Table 1b. Optimal resource alocation by shifts at coordination level for $\mathrm{C}=100$ agents

\begin{tabular}{ccccccc}
\hline & $\mathbf{x}_{\mathbf{1}}$ & $\mathbf{x}_{\mathbf{2}}$ & $\mathbf{x}_{\mathbf{3}}$ & $\mathbf{x}_{\mathbf{4}}$ & $\mathbf{x}_{\mathbf{5}}$ & $\mathbf{x}_{\mathbf{6}}$ \\
\hline $\mathrm{y}_{\mathrm{r}}$ & 1 & 1 & 40 & 93 & 27 & 14 \\
\hline $\mathrm{y}_{\mathrm{s}}$ & 1 & 1 & 8 & 32 & 6 & 5 \\
\hline $\mathrm{y}_{\mathrm{n}}$ & 1 & 1 & 9 & 26 & 21 & 9 \\
\hline
\end{tabular}

The optimal resource alocation by shifts shown in Table $1 \mathrm{~b}$ gives the optimal value of added cost function $\mathrm{F}^{*}(1000)=46529.57(€)$.

Table 2a. Optimal resource alocation at subsystem level for $\mathrm{C}=110$ agents

\begin{tabular}{lccc}
\hline The total available resource, $\mathbf{S}$ [agent $\mathbf{x}$ shift] & $\mathbf{y}_{\mathbf{w}}$ & $\mathbf{y}_{\mathbf{s t}}$ & $\mathbf{y}_{\text {sn }}$ \\
\hline 1100 & 186 & 103 & 67 \\
\hline
\end{tabular}

Table 2b. Optimal resource alocation by shifts at coordination level for $\mathrm{C}=110$ agents

\begin{tabular}{ccccccc}
\hline & $\mathbf{x}_{\mathbf{1}}$ & $\mathbf{x}_{\mathbf{2}}$ & $\mathbf{x}_{\mathbf{3}}$ & $\mathbf{x}_{\mathbf{4}}$ & $\mathbf{x}_{\mathbf{5}}$ & $\mathbf{x}_{\mathbf{6}}$ \\
\hline $\mathrm{y}_{\mathrm{r}}$ & 1 & 1 & 40 & 93 & 27 & 24 \\
\hline $\mathrm{y}_{\mathrm{s}}$ & 1 & 1 & 22 & 38 & 29 & 12 \\
\hline $\mathrm{y}_{\mathrm{n}}$ & 1 & 1 & 9 & 26 & 21 & 9 \\
\hline
\end{tabular}

The optimal resource alocation by shifts shown in Table $2 \mathrm{~b}$ gives the optimal value of added cost function $\mathrm{F}^{*}(1100)=40064.57(€)$. 
Table 3a. Optimal resource alocation at subsystem level for $\mathrm{C}=120$ agents

\begin{tabular}{lccc}
\hline The total available resource, $\mathbf{S}$ [agent $\mathbf{x}$ shift] & $\mathbf{y}_{\mathbf{w}}$ & $\mathbf{y}_{\text {st }}$ & $\mathbf{y}_{\text {sn }}$ \\
\hline 1200 & 199 & 131 & 74 \\
\hline
\end{tabular}

Table 3b. Optimal resource alocation by shifts at coordination level for $\mathrm{C}=120$ agents

\begin{tabular}{ccccccc}
\hline & $\mathbf{x}_{\mathbf{1}}$ & $\mathbf{x}_{\mathbf{2}}$ & $\mathbf{x}_{\mathbf{3}}$ & $\mathbf{x}_{\mathbf{4}}$ & $\mathbf{x}_{\mathbf{5}}$ & $\mathbf{x}_{\mathbf{6}}$ \\
\hline $\mathrm{y}_{\mathrm{r}}$ & 2 & 3 & 41 & 98 & 30 & 25 \\
\hline $\mathrm{y}_{\mathrm{s}}$ & 2 & 1 & 26 & 43 & 36 & 23 \\
\hline $\mathrm{y}_{\mathrm{n}}$ & 1 & 1 & 11 & 27 & 22 & 12 \\
\hline
\end{tabular}

The optimal resource alocation by shifts shown in Table $3 \mathrm{~b}$ gives the optimal value of added cost function $\mathrm{F}^{*}(1200)=34860.03(€)$.

B. Output results for shift duration $m=8$ hours

Table 4a. Optimal resource alocation at subsystem level for $\mathrm{C}=100$ agents

\begin{tabular}{llll}
\hline The total available resource, $\mathbf{S}$ [agent $\mathbf{x}$ shift] & $\mathbf{y}_{\mathrm{w}}$ & $\mathbf{y}_{\text {st }}$ & $\mathbf{y}_{\text {sn }}$ \\
\hline 500 & 84 & 55 & 25 \\
\hline
\end{tabular}

Table 4b. Optimal resource alocation by shifts at coordination level for $\mathrm{C}=100$ agents

\begin{tabular}{cccc}
\hline & $\mathbf{x}_{\mathbf{1}}$ & $\mathbf{x}_{\mathbf{2}}$ & $\mathbf{x}_{\mathbf{3}}$ \\
\hline $\mathrm{y}_{\mathrm{r}}$ & 1 & 54 & 29 \\
\hline $\mathrm{y}_{\mathrm{s}}$ & 1 & 28 & 26 \\
\hline $\mathrm{y}_{\mathrm{n}}$ & 1 & 14 & 10 \\
\hline
\end{tabular}

The optimal resource alocation per shifts shown in Table $3 \mathrm{~b}$ gives the optimal value of added cost function $\mathrm{F}^{*}(500)=49396.34(€)$.

Table 5a. Optimal resource alocation at subsystem level for $\mathrm{C}=110$ agents

\begin{tabular}{llll}
\hline The total available resource, $\boldsymbol{S}$ [agent $\mathbf{x}$ shift] & $\mathbf{y}_{\mathrm{w}}$ & $\mathbf{y}_{\text {st }}$ & $\mathbf{y}_{\text {sn }}$ \\
\hline 550 & 95 & 37 & 38 \\
\hline
\end{tabular}

Table 5b. Optimal resource alocation by shifts at coordination level for $\mathrm{C}=110$ agents

\begin{tabular}{cccc}
\hline & $\mathbf{x}_{\mathbf{1}}$ & $\mathbf{x}_{\mathbf{2}}$ & $\mathbf{x}_{\mathbf{3}}$ \\
\hline $\mathrm{y}_{\mathrm{r}}$ & 1 & 65 & 29 \\
\hline $\mathrm{y}_{\mathrm{s}}$ & 1 & 23 & 13 \\
\hline $\mathrm{y}_{\mathrm{n}}$ & 1 & 21 & 16 \\
\hline
\end{tabular}


The optimal resource alocation by shifts shown in Table $3 \mathrm{~b}$, gives the optimal value of added cost function $\mathrm{F}^{*}(550)=44190.57(€)$.

Table 6a. Optimal resource alocation at subsystem level for $\mathrm{C}=120$ agents

\begin{tabular}{llll}
\hline The total available resource, $S$ [agent $\mathbf{x}$ shift] & $\mathbf{y}_{\mathrm{w}}$ & $\mathbf{y}_{\text {st }}$ & $\mathbf{y}_{\text {sn }}$ \\
\hline 600 & 68 & 66 & 44 \\
\hline
\end{tabular}

Table 6b. Optimal resource alocation by shifts at coordination level for $\mathrm{C}=120$ agents

\begin{tabular}{cccc}
\hline & $\mathbf{x}_{\mathbf{1}}$ & $\mathbf{x}_{\mathbf{2}}$ & $\mathbf{x}_{\mathbf{3}}$ \\
\hline $\mathrm{y}_{\mathrm{r}}$ & 1 & 69 & 28 \\
\hline $\mathrm{y}_{\mathrm{s}}$ & 1 & 37 & 28 \\
\hline $\mathrm{y}_{\mathrm{n}}$ & 1 & 26 & 17 \\
\hline
\end{tabular}

The optimal resource alocation by shifts shown in Table $6 \mathrm{~b}$ gives the optimal value of added cost function $\mathrm{F}^{*}(600)=38984.59(€)$.

From the results above, it could be noticed that increasing the total number of available agents $(C)$ i.e. the total available resource, $\mathrm{S}$, the optimal value of added cost function, $\mathrm{F}^{*}(\mathrm{~S})$, is reduced. In a case of shift duration $m=4$ hours, the absolute minimum of cost function, $\mathrm{F}^{*}(\mathrm{~S})=18614.85$ is reached for the total available resource $\mathrm{S}=1794$ i.e. the total number of available agents $C=180$, while in a case of shift duration $m=8$ hours, the absolute minimum

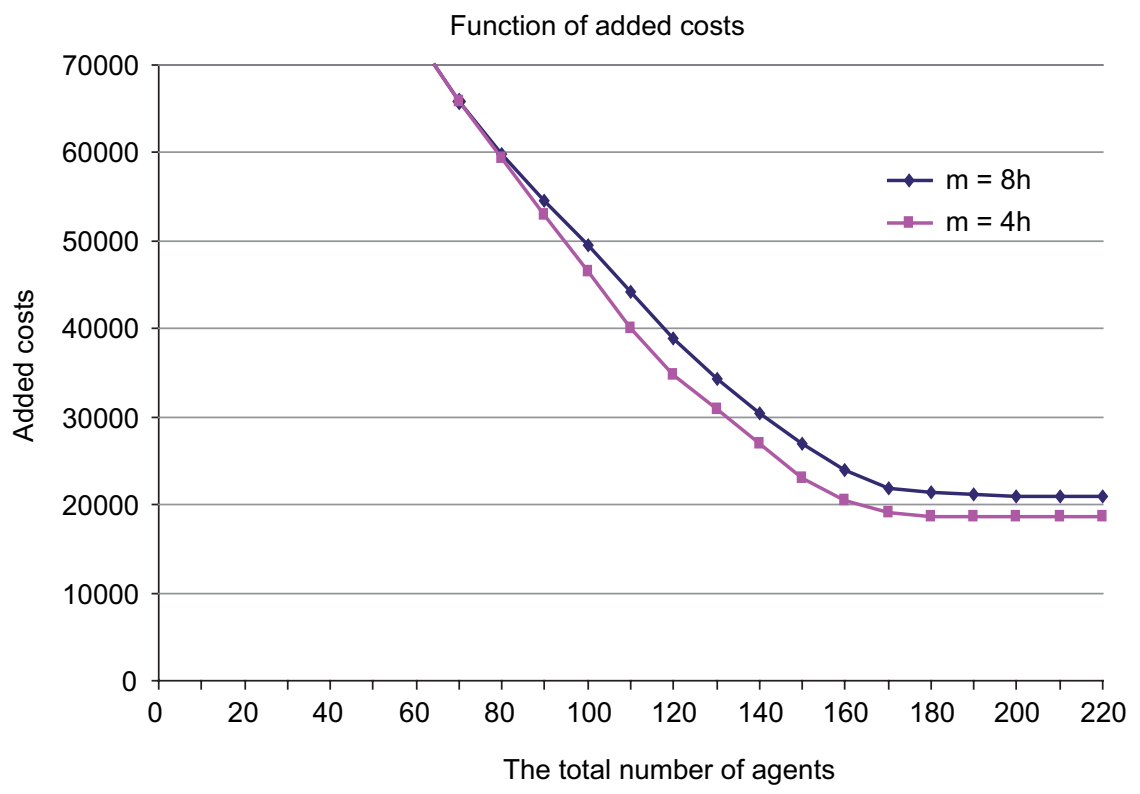

Fig. 7. Added cost function values for $m=4 \mathrm{~h}$ and $m=8 \mathrm{~h}$ 
of cost function $F^{*}(S)=20919.65$ is reahed for $S=995$ i.e. $C=199$. Further increasing the number of agents has no influence on added cost function value reducing. A portion of the obtained results which confirmes this is given by Table 7 .

The comparative results of added cost function values for two shift durations $m=4$ hours and $m=8$ hours are illustrated by Fig. 7 .

It could be noticed that the better results are achived for shorter shift duration $(\mathrm{m}=4 \mathrm{~h})$. The call center long-term operation costs savings are much greater, because the obtained results are calculated only for one week.

Table 7. Part of optimization results for $m=8 \mathrm{~h}$ at coordination level

\begin{tabular}{|c|c|c|c|c|c|c|}
\hline$S$ & $\mathbf{F}_{\mathbf{w}}^{*}$ & $\mathbf{y}_{\mathbf{w}}^{*}$ & $\mathbf{F}_{\text {st }}^{*}$ & $\mathrm{y}_{\mathrm{st}}{ }^{*}$ & $\mathrm{~F}_{\mathrm{sn}}^{*}$ & $y_{s n}{ }^{x}$ \\
\hline 980 & 16687.48 & 161 & 19283.02 & 127 & 20955.69 & 61 \\
\hline 981 & 16687.48 & 161 & 19283.02 & 127 & 20952.30 & 61 \\
\hline 982 & 16687.48 & 161 & 19283.02 & 127 & 20948.91 & 61 \\
\hline 983 & 16687.48 & 161 & 19283.02 & 127 & 20945.52 & 58 \\
\hline 984 & 16687.48 & 161 & 19283.02 & 127 & 20942.14 & 58 \\
\hline 985 & 16687.48 & 161 & 19283.02 & 127 & 20938.75 & 58 \\
\hline 986 & 16687.48 & 161 & 19283.02 & 127 & 20935.36 & 58 \\
\hline 987 & 16687.48 & 161 & 19283.02 & 127 & 20931.97 & 61 \\
\hline 988 & 16687.48 & 161 & 19283.02 & 127 & 20928.59 & 61 \\
\hline 989 & 16687.48 & 161 & 19283.02 & 127 & 20926.54 & 61 \\
\hline 990 & 16687.48 & 161 & 19283.02 & 127 & 20926.51 & 61 \\
\hline 991 & 16687.48 & 161 & 19283.02 & 127 & 20926.51 & 61 \\
\hline 992 & 16687.48 & 161 & 19283.02 & 127 & 20925.11 & 61 \\
\hline 993 & 16687.48 & 161 & 19283.02 & 127 & 20921.72 & 62 \\
\hline 994 & 16687.48 & 161 & 19283.02 & 127 & 20919.68 & 62 \\
\hline 995 & 16687.48 & 161 & 19283.02 & 127 & 20919.65 & 63 \\
\hline 996 & 16687.48 & 161 & 19283.02 & 127 & 20919.65 & 63 \\
\hline 997 & 16687.48 & 161 & 19283.02 & 127 & 20919.65 & 63 \\
\hline 998 & 16687.48 & 161 & 19283.02 & 127 & 20919.65 & 63 \\
\hline 999 & 16687.48 & 161 & 19283.02 & 127 & 20919.65 & 63 \\
\hline 1000 & 16687.48 & 161 & 19283.02 & 127 & 20919.65 & 63 \\
\hline
\end{tabular}

\section{Conclusions}

We have presented a mathematical framework to help think about the way management actions to reduce operational costs and increase quality of service to the customers and increase call center performance. We proposed the two-level dynamic programming approach for optimal allocation of human resources in a call center. This method decomposes the complex 
problem of determination the optimal number of agents by shifts into the several less complex sub-problems (subsystems). By solving these individual sub-problems, the solution of original problem could be obtained efficiently. Multi-dimensionality and large extent of optimization problem was the reason for leaving the typical DP approach and applying the proposed two-level approach. Such approach has shown a number of advantages. The problem may be solved on the step-by-step basis, by finding of local optimums. By introducing this two-level concept, the CPU times as well as the required computer memory resources are improved.

Based on the proposed algorithm, the software application in Visual Basic was developed. The proposed model has several managerial implications. Managers can use our model to obtain the results for optimal allocation of human resources by shifts at any moment, such that the quality of service and the economical constraints are satisfied. The optimal problem solution could be achieved only if the sufficient number of agents/work stations is available. In a case of insufficient number of agents/work stations, managers are able to obtain the results that respond only to proper allocation of agents, without the possibility to improve the quality of service significantly. By applying our resource allocation algorithm, the significant longterm cost savings could be achieved and the efficiency of agent's operation time is improved.

This call center software application is user-friendly which enables simple and easy input data changing, offering the managers high convenience of model using in practice. The practical implementation of the proposed model for various traffic and transport companies are tickets reservation/sales, information about time-tables, positions of parcels and packages (track and trace information), various complains etc.

\section{References}

Barber, G. 2002. Call Center Forecasting and Scheduling: The best of Call Center Management Review. Call Center Press, Annapolis.

Bellman, R. E. 2003. Dynamic Programming. Dover Publications, Mineola, USA.

Borst, S. C.; Mandelbaum, A.; Reiman, M. I. 2004. Dimensioning large call centers, Operation Research 52(1): 7-34. doi:10.1287/opre.1030.0081

Gans, N.; Koole, G.; Mandelbaum, A. 2003. Telephone call centers: tutorial, review and research prospects, Manufacturing and Service Operations Management 5(2): 79-141. doi:10.1287/msom.5.2.79.16071

Garnett, O.; Mandelbaum, A.; Reiman, M. I. 2000. Designing a call center with impatient customers. Bell Laboratories, Lucent Technologies, Murray Hill, NJ.

Green, L. V.; Kolesar, J. P.; Soares, J. 2001. Improving the SIPP Approach For Staffing Service Systems That Have Cyclic Demand, Operations Research 49: 549-564. doi:10.1287/opre.49.4.549.11228

Green, L. V.; Kolesar, J. P.; Whitt, W. 2007. Coping with Time-Varying Demand When Setting Staffing Requirements for a Service System, Production \& Operations Management 16(1): 13-39. doi:10.1111/j.1937-5956.2007.tb00164.x

Koole, G. 2004. Performance analysis and optimization in customer contact centers, in Proceedings of QEST 04, IEEE Computer Society Press, 2-5.

Koole, G. 2007. Call Center Mathematics - A scientific method for understanding and improving contact centers [online]. Available from Internet: <www.math.vu.nl/obp/callcenters $>$.

Radojicic, V. 2004. Forecasting in telecommunications. Faculty of Transport and Traffic Engineering, University of Belgrade (in Serbian). 
Robinett, R. D.; Wilson, D. G.; Eisler, G. R.; Hurtado, J. E. 2005. Applied Dynamic Programming for Optimization of Dynamical Systems. Society for Industrial and Applied Mathematics, Philadelphia.

Rodney, B. Wallace and Whitt, W. 2005. A Staffing Algorithm for Call Centers with Skill-Based Routing, Manufacturing and Service Operations Management 7(4): 276-294. doi:10.1287/msom.1050.0086

Sakalauskas, L.; Zavadskas, E. K. 2009. Optimization and intelligent decisions, Technological and Economic Development of Economy 15(2): 189-196. doi:10.3846/1392-8619.2009.15.189-196

U.S. Bureau of Labor Statistics: Employees on Nonfarm Payrolls by Major Industry. Available from Internet: <http: ||www.bls.gov>.

Whitt, W. 1999. Dynamic Staffing in a Telephone Call Center Aiming to Immediately Answer All Calls, Operations Reasearch Letters 24: 205-212. doi:10.1016/S0167-6377(99)00022-X

Whitt, W. 2002. Stohastic models for the design and management of customers contact centers. Some Research Directions, Columbia University, New York.

Whitt, W. 2005. Engineering Solution of a Basic Call-Center Model, Management Science 51(2): 221-235. doi: $10.1287 /$ mnsc. 1040.0302

Whitt, W. 2006. The Impact of Increased Employee Retention on Performance in a Customer Contact Center, Manufacturing and Service Operations Management 8: 235-252. doi:10.1287/msom.1060.0106

Whitt, W. 2007. What You Should Know About Queuing Models to Set Staffing Requirements in Service Systems, Naval Research Logistics 54(5): 476-474. doi:10.1002/nav.20243

\section{VIEŠOJO TRANSPORTO SISTEMOS VALDYMO CENTRO VEIKLOS MODELIAVIMAS}

\section{S. Tica, V. Radojičić, G. Marković, D. Marković}

Santrauka. Šiame straipsnyje nagrinėjamas valdymo centro veiklos organizavimas operatoriaus darbo požiūriu. Interesantų užklausų skaičius dieną bei ịvairiomis dienomis labai kinta, todèl reikalingo operatorių skaičiaus parinkimas tampa esminiu veiksniu efektyviam darbui užtikrinti. Šio straipsnio paskirtis sukurti matematinį optimalaus išteklių paskirstymo valdymo centre modelį, siekiant užtikrinti tinkamą paslaugų kokybę bet kuriuo laiko momentu, turint optimalų operatorių skaičių. Siekiamas tikslas - rasti geriausią darbuotojų skaičių arba darbo grafiką minimizuojant kasdienes išlaidas ir patenkinant visas sąlygas. Šiai problemai spręsti siūlomas dviejų lygių dinaminio programavimo (DP) algoritmas, nustatantis reikalingą darbuotojų skaičių pamainose. Algoritmas leidžia taip paskirstyti žmogiškuosius išteklius, kad operacijų ịkainiai taptų kuo mažesni. Pateikiamas praktinis didmiesčio viešojo transporto sistemos valdymo centro darbo pavyzdys, palyginami darbo skirtingos trukmés pamainose rezultatai.

Reikšminiai žodžiai: operatorius, valdymo centras, dinaminis programavimas, valdymas, operacija, paslauga, pamaina.

Slaven TICA. Master, Teaching Assistant. Department of Road Traffic. The Faculty of Traffic and Transport Engineering. University of Belgrade. First degree in road traffic engineering, University of Belgrade The Faculty of Transport and Traffic Engineering (1996). Master of Science (2001). Researcher in many National and International Projects. Vice-president of International Association of Public Transport (UITP). Chair of the UITP Light Rail Division. He obtained IRU Academy Certificate of Proffesional Competence for the Road Transport Manager (2007) and Certificate of Proffesional Competence for the Road Transport Manager - International Road Passenger Transport (2007). Author of more than 40 research and scientific articles. Research interests: road traffic, public transport optimization, human resources planning, marketing, strategic management.

Valentina RADOJIČIĆ. Doctor, Associate Professor. Department of Telecommunication Traffic and Networks. The Faculty of Traffic and Transport Engineering. University of Belgrade. First degree in tel- 
ecommunication engineering, University of Belgrade - The Faculty of Transport and Traffic Engineering (1986). Master of Science (1996). Doctor (2002). Researcher in many National and International Projects, Member of National Society of Telecommunication. Author of about 55 research and scientific articles. Research interests: functional organization of telecommunications services, strategic modelling of telecommunication, forecasting of telecommunication services, network planning and design.

Goran MARKOVIĆ. Doctor, Assistance Professor. Department of Telecommunication Traffic and Networks. The Faculty of Traffic and Transport Engineering. University of Belgrade. First degree in telecommunication engineering, University of Belgrade - The Faculty of Transport and Traffic Engineering (1996). Master of Science (2002). Doctor (2007). Researcher in many National and International Projects, Member of IEEE and National Society of Telecommunication. Author of more than 50 research and scientific articles. Research interests: traffic routing problem in communication networks, all-optical networking, optimization problems in telecommunication network design and planning, mathematical programming, forecasting of telecommunication services.

Dejan MARKOVIĆ. Doctor, Associate Professor. Department of Postal Traffic and Networks. The Faculty of Traffic and Transport Engineering. University of Belgrade. First degree in postal traffic engineering, University of Belgrade - The Faculty of Transport and Traffic Engineering (1993). Master of Science (1996). Doctor (2001). Researcher in many National and International Projects. Author of more than 70 research and scientific articles. Research interests: postal traffic, network design and planning, marketing, management, e-commerce, optimization of human resources. 